\title{
Effect of Ta Additions on the Microstructure, Damping, and Shape Memory Behaviour of Prealloyed Cu-Al-Ni Shape Memory Alloys
}

\author{
Safaa N. Saud, ${ }^{1}$ E. Hamzah, ${ }^{2}$ H. R. Bakhsheshi-Rad, ${ }^{3}$ and T. Abubakar ${ }^{2}$ \\ ${ }^{1}$ Faculty of Information Science and Engineering, Management and Science University, 40100 Shah Alam, Malaysia \\ ${ }^{2}$ Faculty of Mechanical Engineering, Universiti Teknologi Malaysia, 81310 UTM Johor Bahru, Johor, Malaysia \\ ${ }^{3}$ Advanced Materials Research Center, Department of Materials Engineering, Islamic Azad University, Najafabad Branch, \\ Najafabad, Iran
}

Correspondence should be addressed to E. Hamzah; esah@fkm.utm.my

Received 27 July 2016; Accepted 6 November 2016; Published 11 January 2017

Academic Editor: Masamichi Yoshimura

Copyright (C) 2017 Safaa N. Saud et al. This is an open access article distributed under the Creative Commons Attribution License, which permits unrestricted use, distribution, and reproduction in any medium, provided the original work is properly cited.

\begin{abstract}
The influence of Ta additions on the microstructure and properties of $\mathrm{Cu}-\mathrm{Al}-\mathrm{Ni}$ shape memory alloys was investigated in this paper. The addition of Ta significantly affects the green and porosity densities; the minimum percentage of porosity was observed with the modified prealloyed $\mathrm{Cu}-\mathrm{Al}-\mathrm{Ni}-2.0 \mathrm{wt} . \%$ Ta. The phase transformation temperatures were shifted towards the highest values after $\mathrm{Ta}$ was added. Based on the damping capacity results, the alloy of $\mathrm{Cu}-\mathrm{Al}-\mathrm{Ni}-3.0 \mathrm{wt} . \% \mathrm{Ta}$ has very high internal friction with the maximum equivalent internal friction value twice as high as that of the prealloyed $\mathrm{Cu}-\mathrm{Al}-\mathrm{Ni} \mathrm{SMA}$. Moreover, the prealloyed $\mathrm{Cu}-$ Al-Ni SMAs with the addition of $2.0 \mathrm{wt}$.\% Ta exhibited the highest shape recovery ratio in the first cycle (i.e., 100\% recovery), and when the number of cycles is increased, this ratio tends to decrease. On the other hand, the modified alloys with 1.0 and 3.0 wt.\% Ta implied a linear increment in the shape recovery ratio with increasing number of cycles. Polarization tests in $\mathrm{NaCl}$ solution showed that the corrosion resistance of $\mathrm{Cu}-\mathrm{Al}-\mathrm{Ni}$-Ta SMA improved with escalating Ta concentration as shown by lower corrosion current densities, higher corrosion potential, and formation of stable passive film.
\end{abstract}

\section{Introduction}

$\mathrm{Cu}$-based shape memory alloys are being considered as a prospective material for applications including highdamping capacity material, sensors, and actuators. Particularly, $\mathrm{Cu}-\mathrm{Al}-\mathrm{Ni}$ alloys are revealed to be appropriate for hightemperature applications due to their high thermal stability at increased temperatures, that is, above $373 \mathrm{~K}\left(100^{\circ} \mathrm{C}\right)[1,2]$. In contrast, the $\mathrm{Cu}-\mathrm{Al}-\mathrm{Ni}$ alloys produced by typical casting methods had to endure the issue of critical brittleness as a response for large grain sizes (around several millimeters) together with large elastic anisotropy [3-5]. For this reason, a number of efforts have aimed to improve the ductility of traditionally cast $\mathrm{Cu}-\mathrm{Al}-\mathrm{Ni}$ alloys via grain refining by the addition of a fourth element, which can include $\mathrm{Ti}, \mathrm{Zr}$, $\mathrm{Mn}, \mathrm{B}, \mathrm{Y}, \mathrm{V}, \mathrm{Co}$, and rare earth metals [6-10]. The grain size of the resulting $\mathrm{Cu}-\mathrm{Al}-\mathrm{Ni}$ alloys was found to range from approximately 100 to $800 \mu \mathrm{m}$. The grain refinement throughout alloying additions displayed enhancement in the mechanical properties of the $\mathrm{Cu}-\mathrm{Al}-\mathrm{Ni}$ alloys. On the other hand, the alloying elements are convenient to burn (atmospheric melting) or perhaps evaporate (vacuum melting) while performing the melting process, causing unrestrained transformation of temperature that can be significantly influenced by the composition of the alloy $[11,12]$. As a result, the mechanical properties of such alloys remained unsatisfactory for most practical applications.

Several investigations have aimed to develop fine-grained $\mathrm{Cu}-\mathrm{Al}-\mathrm{Ni}$ alloys, with a grain size considerably less than $100 \mu \mathrm{m}$, by using various powder metallurgy techniques [13, 14]. These kinds of techniques depended on the $\mathrm{Cu}-\mathrm{Al}-\mathrm{Ni}$ alloy powder, which was prepared by either an inert gas atomization process or mechanical alloying of elemental powders in a high-energy ball mill under inert gas atmosphere [15]. 
The mechanical alloying (MA) method $[16,17]$ is one of the most desired methods; it is indeed reported to be more affordable and also convenient for manufacturing applications. MA is predominantly beneficial to synthesize alloys with significant variance in melting temperatures. The method should prevent the mass loss of the component with the lower melting temperature due to the fact that the synthesis is performed near room temperature. MA is a powder processing approach involving a sequence of repeated welds with fracturing of the powder particles inside a mill. For the synthesis of prealloyed $\mathrm{Cu}-\mathrm{Al}-\mathrm{Ni}$ SMAs with free pores/cracks, numerous common sintering approaches have been studied [18-20]; however, most of these techniques involve lengthy sintering times $(>3 \mathrm{~h})$ and high sintering temperature $\left(1050^{\circ} \mathrm{C}\right)$. Hence, there is strong interest from the PM industry to develop an innovative and superior sintering process with finer microstructures and improved physical and mechanical properties. This is where microwave technology promises to be advantageous [21, 22].

So far, the addition of tantalum has shown a significant effect on the microstructure, mechanical properties, and phase transformation temperature of shape memory alloys [23-25], due to its aptitude to reduce the transformation temperature, increase the thermal stability, and improve the strain recovery $\left(\varepsilon_{\text {reco }}\right)$ and residual strain $\left(\varepsilon_{\text {res }}\right)$ during thermal cycling. Therefore, it is suggested that $\mathrm{Ta}$ is a promising candidate for the alloying element to improve the shape memory property of SMAs [23]. On the other hand, the addition of Ta to Cu-Al-Ni SMAs has not been reported elsewhere; therefore, this research aims to investigate the influence of different amounts of Ta addition on phase transformation, mechanical properties, and corrosion behaviour of prealloyed powders of $\mathrm{Cu}-\mathrm{Al}-\mathrm{Ni}$ SMAs.

\section{Experimental Procedure}

2.1. Sample Preparation. In this research, the elemental powders of $\mathrm{Cu}, \mathrm{Al}$, and $\mathrm{Ni}$, with $\mathrm{Ta}$ as an additional element, were prepared. The specification of the elemental powder and the initial powder mixture is shown in Table 1 . These powders of $\mathrm{Cu}-\mathrm{Al}-\mathrm{Ni}-x \mathrm{Ta}$ SMAs ( $x$ is $1.0,2.0$, and $3.0 \mathrm{wt} . \%$ ) were prepared by mechanical alloying using planetary milling for $1 \mathrm{~h}$ at $300 \mathrm{rpm}$. For the mechanical alloying, a Retsch PM100 planetary ball mill with a zirconium oxide vial was used for $1 \mathrm{~h}$ to confirm the homogeneity of the powder. The rotation speed of the ball mill was $300 \mathrm{rpm}$, and ball to powder ratio was approximately $5: 1$ by weight.

The prealloyed powder was hot pressed into green samples with dimensions of $\phi 15 \mathrm{~mm} \times(\mathrm{L}) 10 \mathrm{~mm}$ for the microstructural characterization and $\phi 15 \mathrm{~mm} \times(\mathrm{L}) 30 \mathrm{~mm}$ for the mechanical test through a 10-ton hand-operated hydraulic press, and a single-act piston die of $15 \mathrm{~mm}$ diameter was utilized. The compaction process was carried out at a constant temperature of $300^{\circ} \mathrm{C}$ for $10 \mathrm{~min}$; the temperature was maintained via an external heater tape connected to a thermoset to maintain the exact temperature. The green samples were placed into a $2.45 \mathrm{GHz}, 0.3-3.0 \mathrm{~kW}$ consistently flexible microwave device (HAMiLab-V3, SYNOTHERM Corp.). The green samples were inserted inside an alumina
TABLE 1: Specification of elemental powders and mixture.

\begin{tabular}{lcccc}
\hline Properties & $\mathrm{Cu}$ & $\mathrm{Al}$ & $\mathrm{Ni}$ & $\mathrm{Ta}$ \\
\hline Size $(\mu \mathrm{m})$ & $150 \pm 7.5$ & $25 \pm 1.25$ & $45 \pm 1.2$ & $45 \pm 1.2$ \\
Purity $(\%)$ & $99 \pm 4.5$ & $99 \pm 4.5$ & $99.5 \pm 5$ & $99.9 \pm 5$ \\
$\begin{array}{l}\text { Composition } \\
\text { (wt.\%) }\end{array}$ & $83.5-x$ & $12.5 \pm 0.7$ & $4 \pm 0.2$ & $\begin{array}{c}x(1.0,2.0, \\
\text { and 3.0) }\end{array}$ \\
\hline
\end{tabular}

sagger and covered with silicon carbide (SiC). The function of $\mathrm{SiC}$ is usually to serve as a microwave susceptor to enable the heating system as well as sintering of the green samples. The samples were sintered by microwave heating at a rate of $20^{\circ} \mathrm{C} / \mathrm{min}$ to $900^{\circ} \mathrm{C}$ for $30 \mathrm{~min}$. Argon gas with a purity of $99.995 \%$ was pumped into the microwave chamber throughout the sintering with the intent to protect against oxidation. To measure the temperature of all samples through the sintering process, a Raytek IR pyrometer was utilized. Prior to the microstructure characterization, the sintered samples were homogenized at $900^{\circ} \mathrm{C}$ for $30 \mathrm{~min}$ and directly quenched in water. Homogenization of the $\mathrm{Cu}-\mathrm{Al}-\mathrm{Ni}$ alloys at temperatures in the $\beta$-phase field followed by rapid cooling produces microstructures formed by metastable phases, which can result in martensitic transformation.

2.2. Porosity Calculation. The green porosity was calculated using the following equation $[26,27]$ :

$$
P=\left\{1-\left(\frac{\rho_{\mathrm{g}}}{\rho_{\mathrm{th}}}\right)\right\} \times 100 \%,
$$

where $\rho_{\mathrm{g}}$ is the green density and can be calculated by division of the calculated weight by the measured volume; and $\rho_{\mathrm{th}}$ is the theoretical density of the samples and can be calculated as follows [28]:

$$
\begin{aligned}
\rho_{\text {th }} & =\left[\rho_{0}^{\mathrm{Cu}} \times(\text { at } \% \mathrm{Cu})+\rho_{0}^{\mathrm{Al}} \times(\text { at } \% \mathrm{Al})+\rho_{0}^{\mathrm{Ni}}\right. \\
& \times(\text { at } \% \mathrm{Ni})+\rho_{0}^{\mathrm{Oxy}} \times(\text { at } \% \mathrm{Oxy})+\rho_{0}^{\text {additives }} \\
& \times(\text { at } \% \text { additives })],
\end{aligned}
$$

where $\rho_{0}^{\mathrm{Cu}}, \rho_{0}^{\mathrm{Al}}, \rho_{0}^{\mathrm{Ni}}, \rho_{0}^{\mathrm{Oxy}}$, and $\rho_{0}^{\text {additives }}$ are the theoretical densities of the base-alloy elements and additives.

2.3. Materials Characterization. The microstructure changes of the prealloyed and homogenized samples were investigated using a field emission-scanning electron microscope (FESEM), Zeiss-LEO Model 1530, operated at $10 \mathrm{kV}$ coupled with energy-dispersive spectroscopy (EDS) operated at $10 \mathrm{kV}$. The results of EDS were indicated in accordance with a standardless semiquantitative analysis and an error bar in value of 5\% was added to each reading. The phase and crystal structure were identified using a D5000 Siemens Xray diffractometer fitted with a $\mathrm{Cu} \mathrm{K} \alpha \mathrm{X}$-ray source with a locked coupled mode, a $2 \theta$ range between $30^{\circ}$ and $80^{\circ}$, and a $0.05^{\circ}$ /s scanning step. The transformation temperatures of the mechanically alloyed $\mathrm{Cu}-\mathrm{Al}-\mathrm{Ni}$ alloy specimens with and without addition were evaluated via differential scanning calorimetry (DSC) at a heating/cooling rate of $10^{\circ} \mathrm{C} / \mathrm{min}$. 
2.4. Mechanical Test. The internal fractions of the $\mathrm{Cu}-\mathrm{Al}-\mathrm{Ni}$ alloys with and without addition were evaluated by performing the damping test on the specimens in the martensitic state, wherein subsize test specimens with the dimension of $19 \mathrm{~mm}$ $\times 3 \mathrm{~mm} \times 2 \mathrm{~mm}$ were prepared. The damping tests were carried out in a DMA Q800 dynamic mechanical analyzer in single-cantilever mode at a constant vibration frequency of $1 \mathrm{~Hz}$ and displacement of $0.05 \mathrm{~mm}$, with a temperature range from $20^{\circ} \mathrm{C}$ to $300^{\circ} \mathrm{C}$ and a constant heating/cooling rate of $5^{\circ} \mathrm{C} / \mathrm{min}$. To measure the shape memory recovery of the prealloyed samples under multicycles, isothermal compressive loading and unloading were carried out at a tested temperature of $200^{\circ} \mathrm{C}$, and, after each cycle, the sample was heated to $T>A_{f}$, that is, $\approx 300^{\circ} \mathrm{C}$, to obtain the shape recovery.

2.5. Corrosion Test. For potentiodynamic polarization (PDP) tests, cylindrical specimens with a surface area of $1 \mathrm{~cm}^{2}$ were prepared. PDP was carried out in an open-air glass cell containing $350 \mathrm{~mL}$ of $3 \mathrm{wt} . \% \mathrm{NaCl}$ solution using a potentiostat (PARSTAT 2263 Princeton Applied Research). A threeelectrode cell was used for the PDP tests, where a saturated calomel electrode (SCE) was used as the reference electrode, a graphite rod as the counter electrode, and an alloy specimen as the working electrode. The samples were immersed in the SBF for $1 \mathrm{~h}$ prior to the PDP test to establish the open-circuit potential. The samples were immersed in the $\mathrm{NaCl}$ solution for $1 \mathrm{~h}$ prior to the PDP test to establish the open-circuit potential. All experiments $(n=3$, where $\mathrm{n}$ indicates the number of replicates) were carried out in the range between $-250 \mathrm{mV}$ in the cathodic direction and $+500 \mathrm{mV}$ in the anodic direction relative to the open-circuit potential at a constant scan rate of $0.167 \mathrm{mV} / \mathrm{s}$. The polarization resistance $\left(R_{P}\right)$ was calculated according to the following equation $[29,30]$ :

$$
R_{P}=\frac{\beta_{a} \beta_{c}}{2.3\left(\beta_{a}+\beta_{c}\right) i_{\text {corr }}},
$$

where $i_{\text {corr }}$ is corrosion current density, $\beta_{c}$ is cathodic Tafel slope, and $\beta_{a}$ is anodic Tafel slope of the specimens. The corrosion rate $\left(C_{R}\right)$ of the samples, obtained from the corrosion current density, was calculated according to [31]:

$$
C_{R}=22.85 i_{\text {corr }} \text {. }
$$

Immersion testing was carried out according to ASTM G1-03. Specimens with a diameter of $10 \mathrm{~mm}$ and thickness of $10 \mathrm{~mm}$ were immersed in a beaker containing $200 \mathrm{~mL}$ of $3 \mathrm{wt} . \% \mathrm{NaCl}$ solution for 30 days. The immersion tests were repeated at least once to verify the reproducibility of the results.

\section{Results and Discussion}

3.1. Green Density and Porosity. The variation of green density and porosity of the modified and unmodified alloys as a function of Ta amount is shown in Figures 1(a)-1(c). It can be clearly seen that the addition of Ta has produced a significant effect on the porosity density, in which the addition of $2.0 \mathrm{wt} . \%$ Ta led to an increase in the green density from
$5.354 \mathrm{~g} / \mathrm{cm}^{3}$ to $6.869 \mathrm{~g} / \mathrm{cm}^{3}$, in consequence of reducing the green porosity from $12.96 \%$ to $7.5 \%$. On the other hand, based on the micrographs in Figure 1(a), it was found that the $\mathrm{Cu}$ Al-Ni SMA contains some semimicron-sized pores and that these pores were distributed randomly in the microstructure. The area fractions of the pores were calculated using image processing software known as isolution that also confirmed the same trend of decrement with the addition of Ta in which the lowest area fraction of pores was observed with $2.0 \mathrm{wt} . \%$ Ta addition. With further increase in Ta amount to $3.0 \mathrm{wt} . \%$, the area fraction of pores increased, as shown in Figure 1(b). Utilizing isolution image processing software (isolution DT) and in accordance with the ASTM E112-12, the grain sizes of the modified and unmodified prealloyed samples were evaluated as indicated in Figure 1(c). It was observed that the grain size of the modified prealloyed samples significantly decreased, and the smallest grain size was indicated with the prealloyed sample of $2.0 \mathrm{wt} . \% \mathrm{Ta}$ addition. This kind of reduction is mainly related to the effect of mechanical alloying, which also suggested that approximately 2 at.\% Ta can be forced into the $\mathrm{Cu}$ lattice to form a supersaturated $\mathrm{Cu}$ rich solid solution $[32,33]$ and produce a grain refinement. Darling et al. [32] have also revealed that the grain boundaries are more sensitive to the applied temperature of treatment and diffusion rate of Ta phase. In general, the grain size of $\mathrm{Cu}-\mathrm{Al}-\mathrm{Ni}$ SMA which is produced by conventional casting was determined to be 300-1400 $\mu \mathrm{m}$ [34-36], even though the alloying elements and thermal treatments were applied.

3.2. Microstructural Investigations. Figures 2(a)-2(h) show micrographs of prealloyed and homogenized $\mathrm{Cu}-\mathrm{Al}-\mathrm{Ni}$ SMAs associated with the chemical analysis of the homogenised samples. From the microstructure of prealloyed samples (see Figures 2(a)-2(d)), neck formation between the powder particles can be easily seen; these necks are caused by the cold working of the element powder that occurred during the mechanical alloying (ball-milling process). From the FESEM high-resolution images (Figures $2(\mathrm{e})-2(\mathrm{~h})$ ), it can be seen that there are two phases with different morphologies, plate-like and needle-like, with a self-accommodating configuration inside the merged grains. These phases are $\beta_{1}^{\prime}$ and $\gamma_{1}^{\prime}$ which are formed as thermally induced martensites and varied in terms of thickness and orientation after the addition of Ta. The $\gamma_{1}^{\prime}$ phase formed as a coarse variants/platelike phase, while the $\beta_{1}^{\prime}$ phase formed as a needle-like phase between the $\gamma_{1}^{\prime}$ phases. The needle-like phase of $\beta_{1}^{\prime}$ martensite has a very pronounced thermoelastic behaviour, which can be attributed to its controlled growth in the selfaccommodating groups [37]. However, when Ta was added, new phases were formed and the volume fraction of these precipitates varied according to the amount of Ta added. It is well known that $\mathrm{Ta}$ is an attractive element that causes the formation of second-phase/intermetallic compounds after addition [25, 38]. On the other hand, it was found that these precipitates were depleted in the $\mathrm{Al} / \mathrm{Ni}$ matrix and, hence, the formation of $\beta_{1}^{\prime}$ martensite is promoted [36]. These precipitates accommodate the $\gamma_{1}^{\prime}$ and $\beta_{1}^{\prime}$ parent phases, and their accommodation is in a coherent or mostly semicoherent 


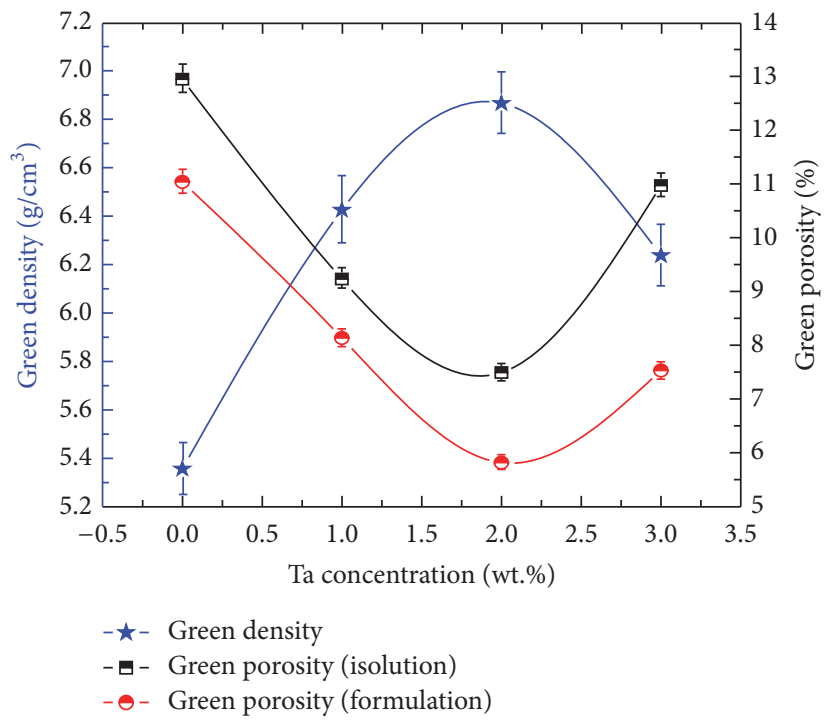

(a)
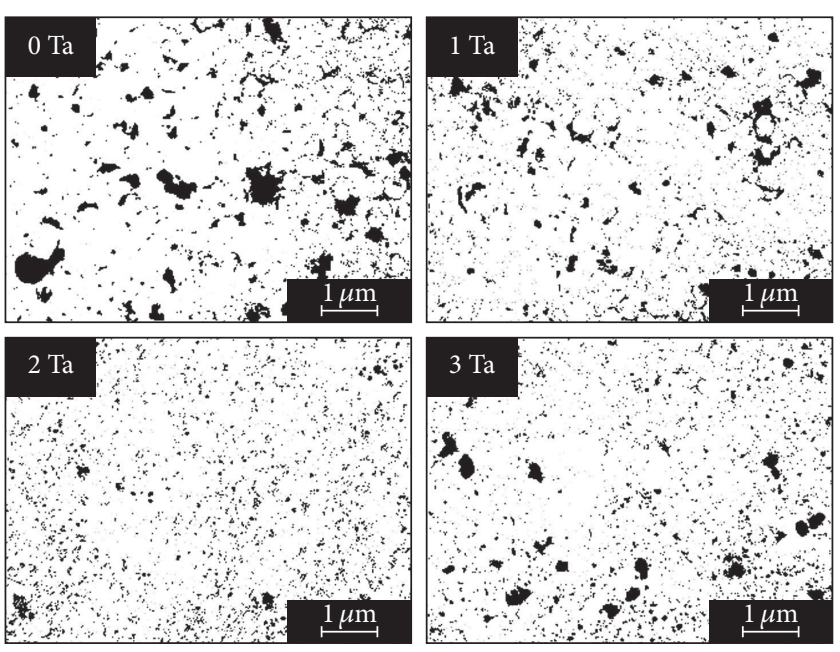

(b)

\begin{tabular}{|c|c|c|c|c|}
\hline Statistics & $\begin{array}{c}\text { Equal circle } \\
\text { diam }\end{array}$ & $\begin{array}{c}\text { Min ferret } \\
\text { diam }\end{array}$ & $\begin{array}{l}\text { Max ferret } \\
\text { diam }\end{array}$ & $\begin{array}{l}\text { Avg. ferret } \\
\text { diam }\end{array}$ \\
\hline$\overline{M i n}$ & 2.19 & 1.04 & 2.34 & 2.01 \\
\hline Max & 32.91 & 27.95 & 57.87 & 43.22 \\
\hline Mean & 9.48 & 8.38 & 15.15 & 12.95 \\
\hline Std. dev. & 4.17 & 4.14 & 6.31 & 5.18 \\
\hline Variance & 17.45 & 17.15 & 39.87 & 26.9 \\
\hline Skew & 1.11 & 1.16 & 1.28 & 1.16 \\
\hline Excess & 1.72 & 1.73 & 2.83 & 2.02 \\
\hline Var. coeff. & 44.06 & 49.41 & 47.99 & 47.15 \\
\hline Sum & 17305.15 & 15298.69 & 24011.51 & 20075.62 \\
\hline \# samples & 1825 & 1825 & 1825 & 1825 \\
\hline \# blocks & 1 & 1 & 1 & 1 \\
\hline $95 \%$ confidence & 0.19 & 0.19 & 0.28 & 0.23 \\
\hline Relative accuracy & 2.02 & 2.26 & 2.2 & 2.16 \\
\hline & & & & \\
\hline & & & & 8 \\
\hline & & & & \\
\hline & & & & \\
\hline & & & & \\
\hline & & & & \\
\hline & 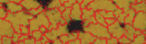 & & & \\
\hline & & & $1 \mu \mathrm{m}$ & \\
\hline
\end{tabular}

(c)

Figure 1: ( $\mathrm{a}$ and $\mathrm{b}$ ) Calculated green porosity and density of $\mathrm{Cu}-\mathrm{Al}-\mathrm{Ni}-x \mathrm{Ta}$ SMA using formulation and image process contrast. (c) Grain size measurement in accordance with ASTM E112-12.

mode that depends on the precipitates' sizes and crystalstructure orientations relative to the parent phase [39]. Therefore, during the transformation of the precipitate into a single martensite variant after being surrounded by matrix, the precipitate leaves its place as a vacancy. However, the occurrence of an intrinsic deformation leads to a variety of other precipitates that are severely deformed during the transformation, and, thus, the precipitate maintains its own shape. It is well known that the microstructure and hence the mechanical behaviour of $\mathrm{Cu}-\mathrm{Al}-\mathrm{Ni}$ alloys change with the alloy composition and the processing routes to which the samples are subjected. The chemical compositions of the formed phases/precipitates in $\mathrm{Cu}-\mathrm{Al}-\mathrm{Ni}-2.0 \mathrm{wt} . \% \mathrm{Ta}$ alloys were examined using EDS and are shown in Figure 2(i). It was found that the amount of elemental $\mathrm{Ta}$ in different microstructural locations was significantly changed based on 

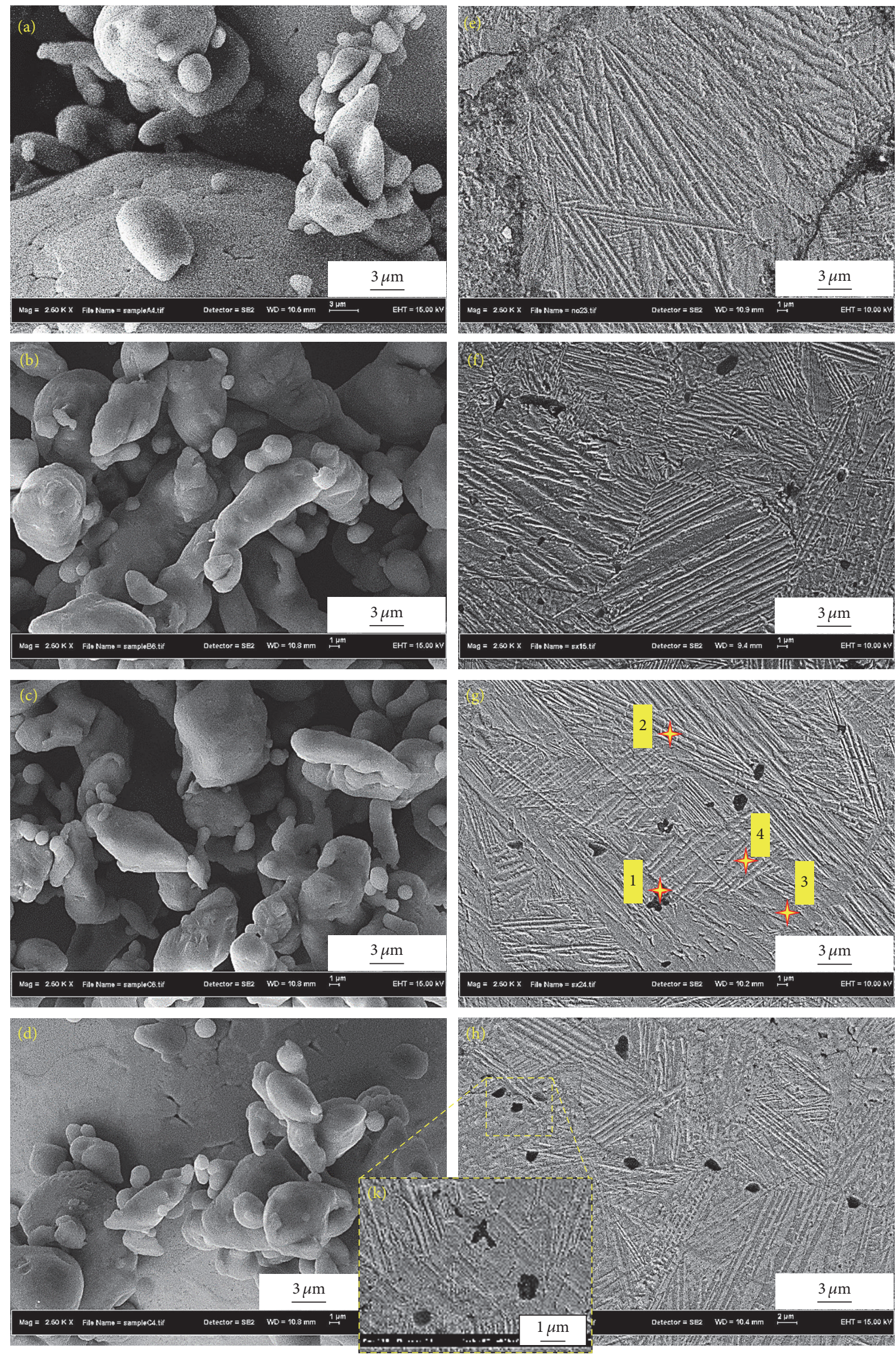

FIgUre 2: Continued. 

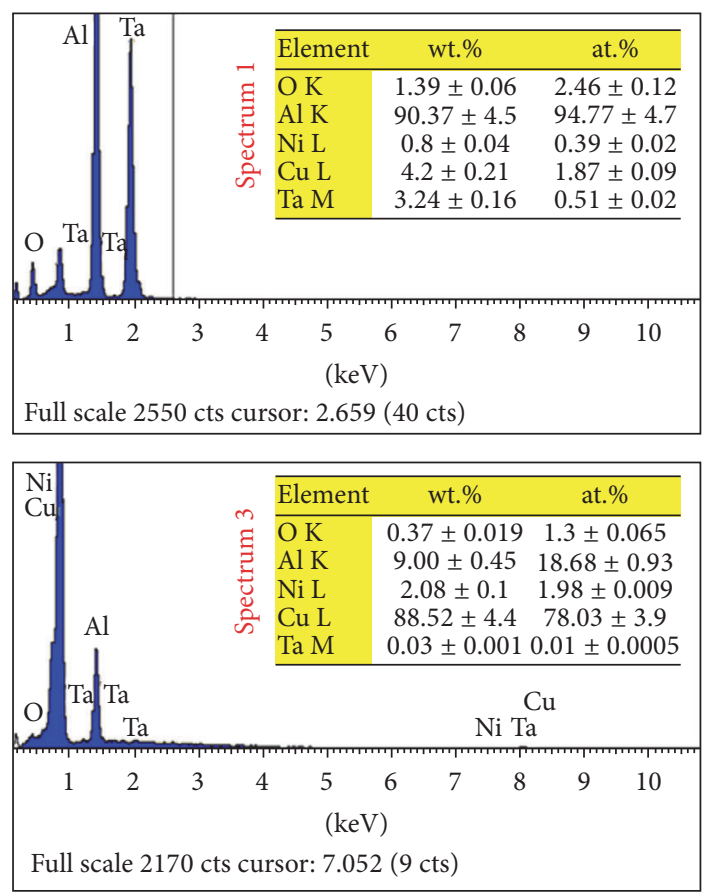
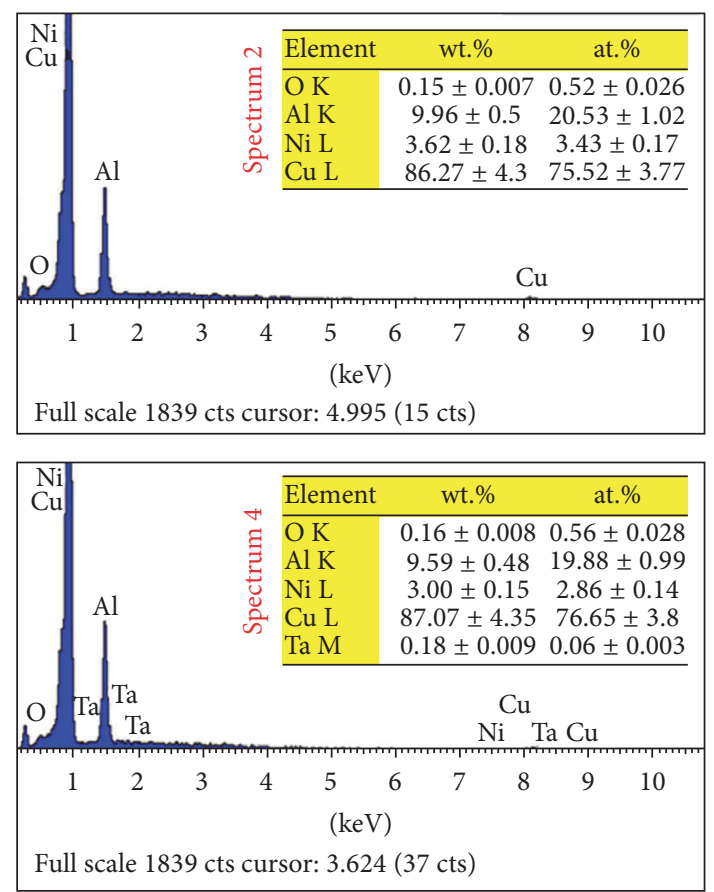

(i)

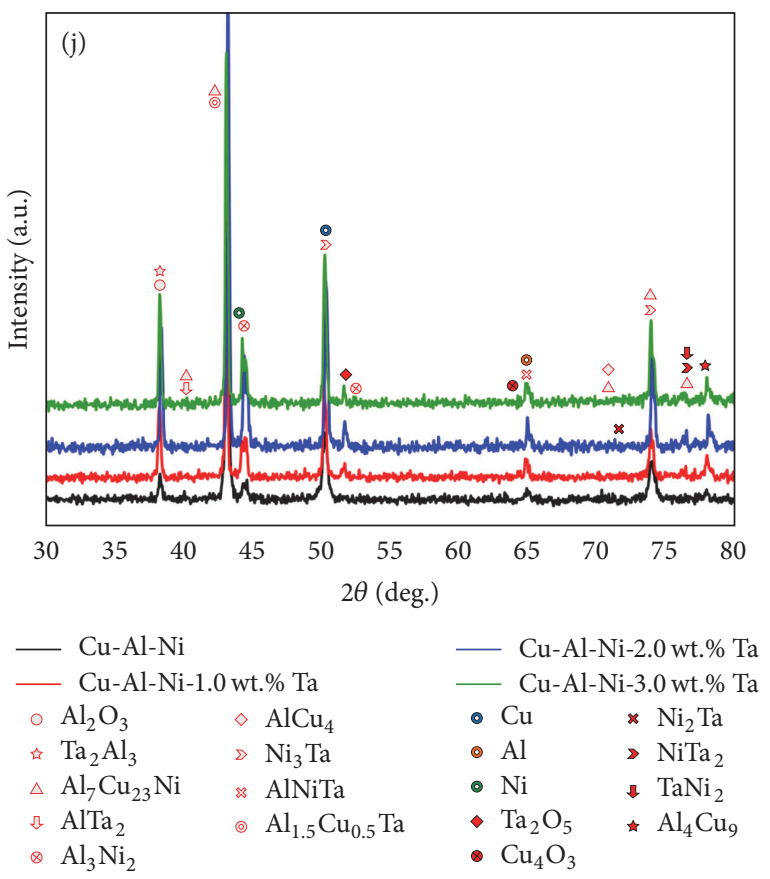

Figure 2: Morphologies of the milled powder and homogenized Cu-Al-Ni SMAs with and without Ta addition: ((a) and (e)) 0 wt.\% Ta; ((b) and (f)) 1.0 wt.\% Ta; ((c) and (g)) 2.0 wt.\% Ta; ((d) and (h)) 3.0 wt.\%; (i) EDS spectrums, (j) XRD diffraction of Cu-Al-Ni-2.0 wt.\% Ta SMA; and $(\mathrm{k})$ the magnified porosity with $3.0 \mathrm{wt} . \%$ Ta addition.

the type of the formed phases/precipitates. Furthermore, the percentage of oxygen was found to decrease after the addition of Ta and homogenization.

The XRD patterns of the homogenized $\mathrm{Cu}-\mathrm{Al}-\mathrm{Ni}-x \mathrm{Ta}$ SMAs with different percentages of $\mathrm{Ta}$ are presented in Figure 2(j). Indexing of these patterns shows that these only consist of martensite phases $\gamma_{1}^{\prime}$ and $\beta_{1}^{\prime}$ having a monoclinic structure as main phases along with some other precipitates/intermetallic compounds that are also formed after being homogenized at $900^{\circ} \mathrm{C}$ for $1 \mathrm{~h}$. After the addition of Ta, the scanned peaks changed in terms of $2 \theta$ and intensity, which shows that the XRD patterns of $\mathrm{Cu}-\mathrm{Al}-\mathrm{Ni}$ SMA are sensitive to 


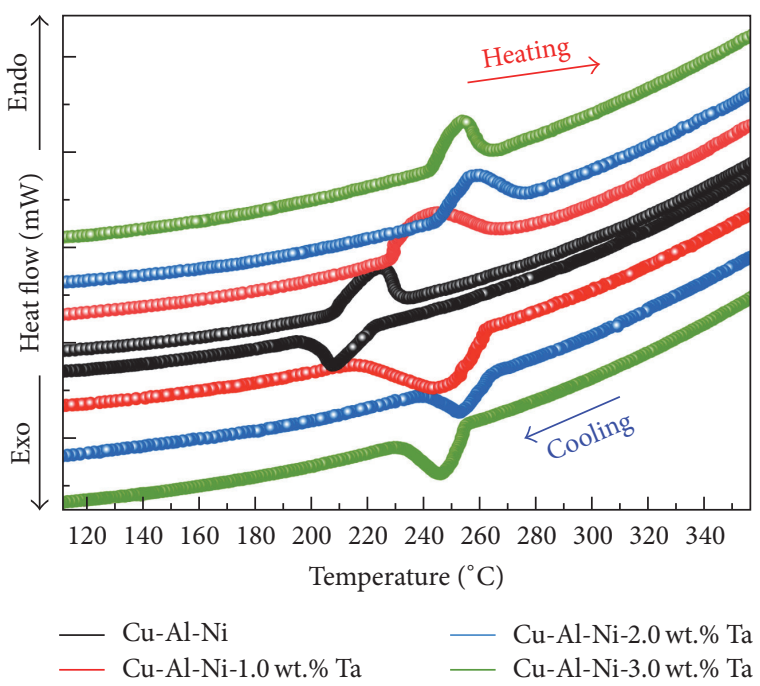

FIgURE 3: Endothermic and exothermic curves of $\mathrm{Cu}-\mathrm{Al}-\mathrm{Ni}-x \mathrm{Ta}$ SMAs.

TABLE 2: Transformation temperature of Cu-Al-Ni SMA with and without Ta additions.

\begin{tabular}{lcccc}
\hline \multirow{2}{*}{ Alloy } & \multicolumn{4}{c}{ Transformation temperatures $\left({ }^{\circ} \mathrm{C}\right)$} \\
& $A_{s}$ & $A_{f}$ & $M_{s}$ & $M_{f}$ \\
\hline Cu-Al-Ni & 207 & 235 & 226 & 196.25 \\
Cu-Al-Ni-1.0 wt.\% Ta & 225.8 & 267.57 & 263 & 211.8 \\
Cu-Al-Ni-2.0 wt.\% Ta & 242.7 & 277.4 & 265.6 & 237.9 \\
Cu-Al-Ni-3.0 wt.\% Ta & 240.5 & 265.6 & 256.8 & 229 \\
\hline
\end{tabular}

the amount of added Ta. On the other hand, the matrix of $\mathrm{Cu}$ Al-Ni SMA as the predominant phase was always retained, even though Ta amounts varied.

3.3. Transformation Temperatures. The endothermic and exothermic curves of the prealloyed samples of $\mathrm{Cu}-\mathrm{Al}-\mathrm{Ni}$ with and without Ta addition are shown in Figure 3 and the determined data are tabulated in Table 2. The endothermic curve during the heating represented the transformation of martensite to austenite phase, and this transformation is represented by the transformation temperatures of $A_{s}$ and $A_{f}$, austenite start and finish, respectively. Meanwhile, the exothermic curve during the cooling represented the transformation of austenite to martensite phase, which is represented by the transformation temperatures of $M_{s}$ and $M_{f}$, martensite start and finish, respectively. From Figure 3, it can be seen that the forward and backward transformations show one-step transformation in the modified and unmodified prealloyed samples due to the existence of a smooth single peak. The result reveals that the transformation temperatures are shifted towards higher temperatures. When the amount of Ta was approximately $1.0 \mathrm{wt} . \%$, the transformation temperatures were slightly increased. Further increasing the amount of Ta to $2.0 \mathrm{wt} . \%$, the transformation temperatures were rapidly increased compared with the unmodified alloy.

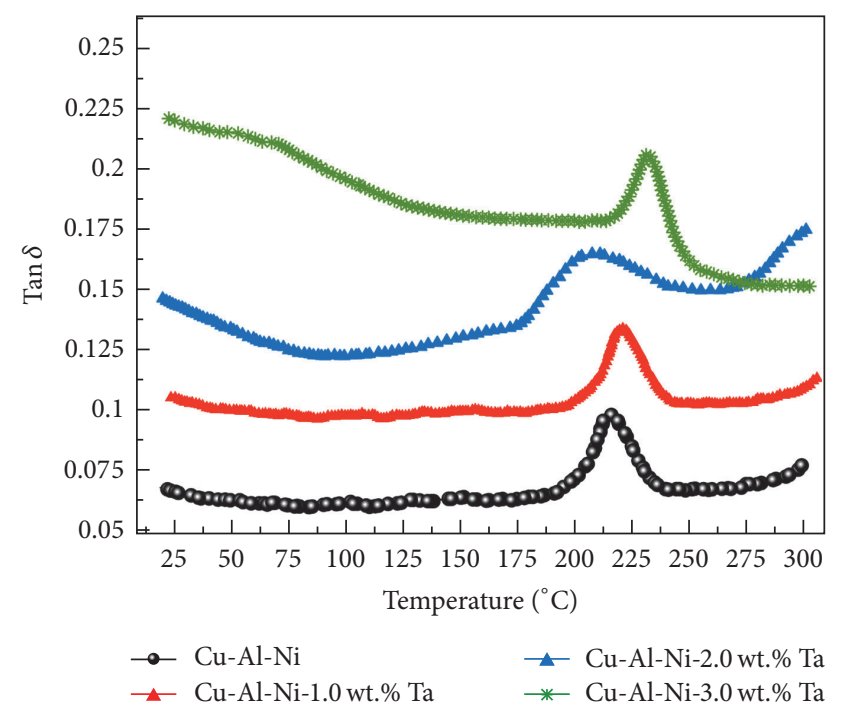

Figure 4: Internal friction heating curves of $\mathrm{Cu}-\mathrm{Al}-\mathrm{Ni}-x \mathrm{Ta}$ SMAs.

However, the addition of $3.0 \mathrm{wt} . \%$ Ta led to decreasing the transformation temperatures compared with $2.0 \%$ Ta sample. It is well known that the transformation temperatures are mainly affected by the presence of precipitates, porosity, and their volume fraction [35, 40, 41]. Based on the micrographs in Figures 1(a) and 1(b), it is apparent that the percentage of porosity was increased as the percentage of Ta increased to 2.0 and $3.0 \mathrm{wt} . \%$, and thus the transformation temperatures decreased.

\subsection{Mechanical Properties}

3.4.1. Damping. In order to obtain the most accurate damping behaviour of the materials, Tan $\delta$ is the most suitable measurement, as it can give the ideal evolution of the signal over time. Within the low frequency, the peak of Tan $\delta$ during the martensitic transformation is mainly attributed to the transient internal friction $[42,43]$. When the alloy is set at a certain temperature in an isothermal condition, the value of $\operatorname{Tan} \delta$ is significantly decreased, which is associated with delaying the inherent internal friction and the intrinsic internal friction. Figure 4 shows the internal friction (Tan $\delta$ ) against the applied temperature, in which, based on Tan $\delta$ curve, there is only one peak observed for the modified and unmodified alloys which is related to the phase transition. It was found that the addition of Ta has significantly varied in the value of $\operatorname{Tan} \delta$, obtaining the highest value with the addition of $3.0 \mathrm{wt} . \%$ of Ta with respect to the base alloy. It can be also seen that the relaxation peak increased with increasing $\mathrm{Ta}$ amount. This is evidently explained by the presence of a multitude of Ta precipitates, which interfere with the movement of dislocations in the martensite phase and constitute the primary reason for the relaxation event.

In order to determine the influence of porosity on the damping behaviour and, based on previous studies [44, 45], an effective parameter, namely, equivalent internal friction 
$\left(Q_{\text {eqv }}^{-1}\right)$, was proposed, and the value of this parameter can be determined using the following formula:

$$
Q_{\mathrm{eqv}}^{-1}=\frac{Q^{-1}}{(1-P)},
$$

where $Q^{-1}$ is the internal friction and $P$ is the porosity. The results show that the equivalent internal friction was found to be in the consequence of $3.0 \mathrm{wt} . \% \mathrm{Ta}>2.0 \mathrm{wt} . \% \mathrm{Ta}>1.0 \mathrm{wt} . \%$ $\mathrm{Ta}>0 \mathrm{wt} . \% \mathrm{Ta}$, in which the modified alloy with $3.0 \mathrm{wt} . \% \mathrm{Ta}$ has highest $Q_{\text {eqv }}^{-1}$, which is almost twice that of the unmodified alloy. The mechanisms of internal friction for the $\mathrm{Cu}-\mathrm{Al}-\mathrm{Ni}$ SMAs are mainly related to the martensitic interfaces and transformation behaviour. During the mechanical loading and unloading and the thermal process, the martensite $\leftrightarrow$ austenite phase transformation exhibits a dramatic latticesoftening phenomenon, and twin boundaries in the austenite phase are easier to form than in the martensite, which resulted in a higher damping capacity.

On the other hand, the presence of porosity may lead to making a difference in the elastic modulus and thermal expansion with respect to the matrix and thus cause a high thermal stress concentration around the pores [46]. In other words, that causes the pores to have a very complicated and inhomogeneous stress-strain state, in which this state causes a dilatation and distortion of pores and, hereafter, the dilatation and distortion energy increased. The dilatation and distortion of pores incorporate a number of processes including dislocation motion and formation which is certainly initialized in the material to relax stress concentration and then contributes to the dissipation of the elastic energy [47]. It is usually apparent that when the damping derives from a dislocation mechanism, it can be explained by strain amplitude reliance [48]. In addition, the martensitic transformation is also controlled slightly within the presence of porosity in SMAs and the index of energy dissipation, and, therefore, the value of Tan $\delta$ declines with increasing the density of porosity and decreasing of the grain size [47]. This statement can be supported by the lower number of IF values for the unmodified alloy that has the highest density of porosity, as indicated in Figures 1(a) and 1(b).

3.4.2. Shape Memory Characteristics. Figures 5(a)-5(d) show the stress-strain curves measured for each training cycle of the modified and unmodified prealloyed $\mathrm{Cu}-\mathrm{Al}-\mathrm{Ni}$ SMAs. The stress is plotted against the prestrain that performed at a temperature of $200^{\circ} \mathrm{C}$, and the indicated arrows within $x$-axis represent the strain recovery by shape memory effect at the corresponding cycle that was measured at a temperature of $300^{\circ} \mathrm{C}$. In accordance with the s-s curves, it was found that the compressive stress increased after the addition of $\mathrm{Ta}$, which has increased almost fourfold compared with the unmodified alloys. On the other hand, the shape memory recovery was also enhanced after the addition of Ta. The highest shape memory recovery was indicated with the modified alloy of 2.0 wt.\% Ta (Figure 5(c)) which shows almost 100\% recovery after being heated above $A_{f}$ (i.e., $300^{\circ} \mathrm{C}$ ) at the first cycle; however, as a further number of cycles were performed, this ratio tended to decrease. Both alloys of $1.0 \mathrm{wt} \%$ and
3.0 wt.\% show a linear increment in the strain recovery with increasing number of cycles, as observed in Figures 5(b) and 5(d). The fluctuations in the residual strain and recovery strain are mainly dependent on the direction and movement of martensite interfaces and dislocations $[49,50]$. When the multitraining cycles were performed, the martensite variants were oriented unidirectionally, and, therefore, the plastic strain was stored in the samples. Within a certain number of cycles, the local stress is formed and results in increases in the density of dislocation and imperfections, which in opposite causes interlocking the dislocations and, thus, suppressing the movement of the martensite variants. As a result, the phase is unable to transform to the martensite phase and more residual plastic deformation is stored in the sample $[51,52]$. On the other hand, increasing the number of thermal loading and unloading cycles can also result in increases in the volume fraction of the martensite variants. As a consequence, the structure of dislocations and martensitic variants remained constant during the training cycles, and, therefore, the shape memory effect decreased. As further numbers of training cycles are increased, associated with inducing a certain stress at a specific position, the density of dislocation reached the saturation level and led to the shape memory characteristics being stabilized.

3.5. Electrochemical and Immersion Test. Typical potentiodynamic polarization curves of base $\mathrm{Cu}-\mathrm{Al}-\mathrm{Ni} \mathrm{SMA}$ and $\mathrm{Cu}-$ Al-Ni- $x$ Ta $(x=1.0,2.0$, and 3.0 wt.\%) SMAs are plotted in Figure 6. Corrosion potential $\left(E_{\text {corr }}\right)$, corrosion current density $\left(i_{\text {corr }}\right)$, and polarization resistance $\left(R_{P}\right)$ of the SMA samples are presented in Table 3. $E_{\text {corr }}$ of SMA containing Ta was nobler compared with the base SMA sample. $E_{\text {corr }}$ of the $\mathrm{Cu}-\mathrm{Al}-\mathrm{Ni}-1.0 \mathrm{wt}$.\% Ta sample was approximately $-220.5 \mathrm{mV}_{\mathrm{SCE}}$, whereas that of the base SMA sample was around $-261.6 \mathrm{mV}_{\mathrm{SCE}}$. The $\mathrm{Cu}-\mathrm{Al}-\mathrm{Ni}-3.0 \mathrm{wt} . \% \mathrm{Ta}$ sample evidently had more positive $E_{\text {corr }}\left(-159.3 \mathrm{mV}_{\mathrm{SCE}}\right)$ compared with the $\mathrm{Cu}-\mathrm{Al}-\mathrm{Ni}-2.0 \mathrm{wt} . \%$ Ta sample $\left(-185.1 \mathrm{mV}_{\mathrm{SCE}}\right)$. This illustrated that the addition of Ta to the base SMA sample ennobles the open-circuit potential. In fact, the SMA containing $3.0 \mathrm{wt}$.\% Ta indicates the nobler pitting potential that causes a decline of pitting susceptibility and increases pitting corrosion resistance [53]. Polarization curves also display that $i_{\text {corr }}$ of the base SMA and Cu-Al-Ni-1.0 wt.\% Ta SMA was 117.6 and $78.4 \mu \mathrm{A} \mathrm{cm}^{-2}$, respectively. The base SMA is not passivated and dissolves actively, forming a corrosion product film [54]. Thus, the Cu-Al-Ni-1.0 wt.\% Ta SMA presented better corrosion resistance than that of the base SMA. Addition of 2.0 and $3.0 \mathrm{wt}$. $\%$ Ta to the base SMA reduced $i_{\text {corr }}$ to 32.7 and $12.8 \mu \mathrm{A} \mathrm{cm}^{-2}$, respectively. The higher corrosion resistance of the SMA containing higher Ta concentration is due to the rapid formation of a passive film with a highly protective quality and high uniformity [54].

From the curve, it can be observed that $\beta_{a}$ is $\sim 0.07 \mathrm{~V} /$ decade for the SMA containing Ta. This value is close to the theoretical and experimental value of $0.06 \mathrm{~V} /$ decade for copper in chloride media at room temperature [55]. $R_{p}$ values indicated a positive influence of Ta additions on the corrosion behaviour of Cu-Al-Ni SMA alloy. Thus, $R_{p}$ values 


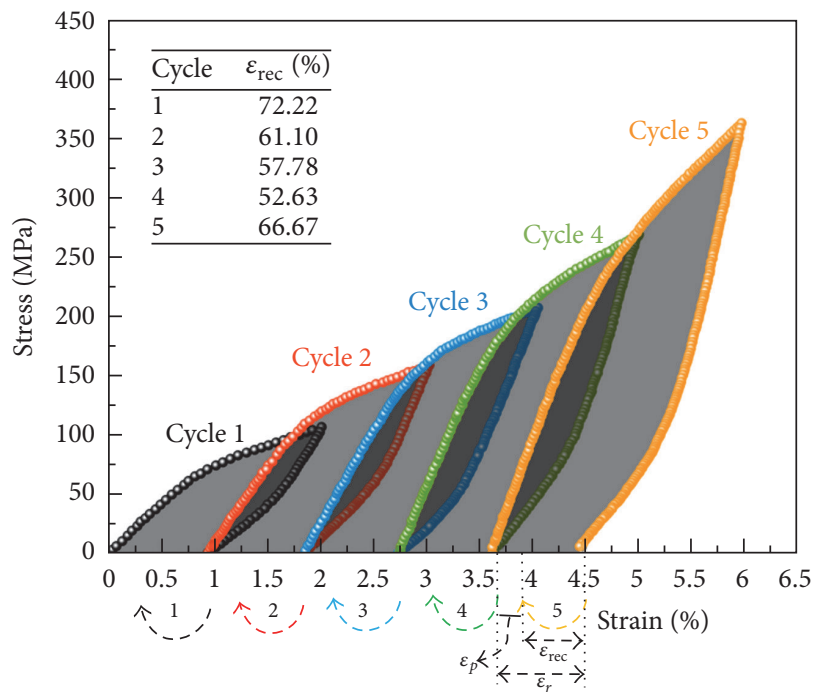

(a)

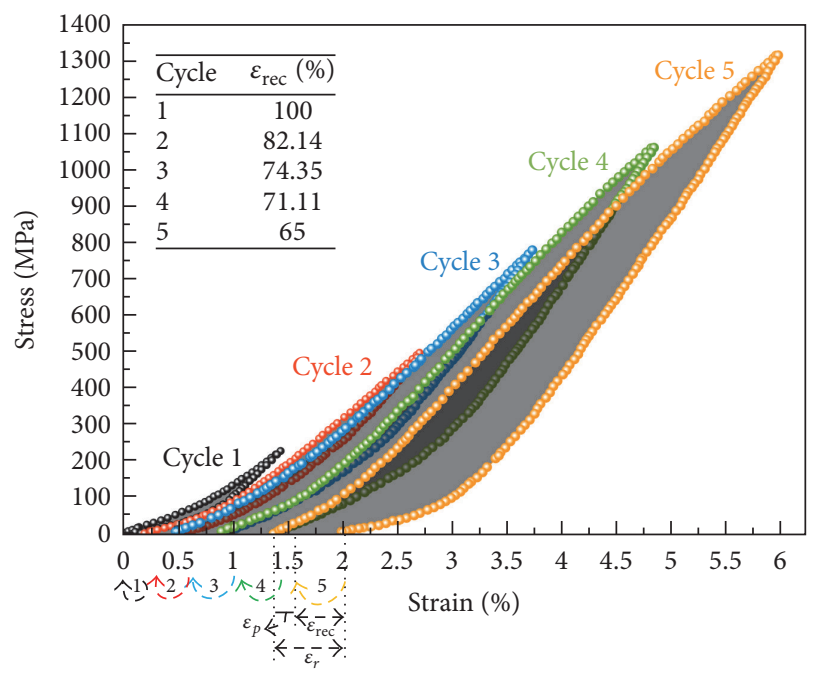

(c)

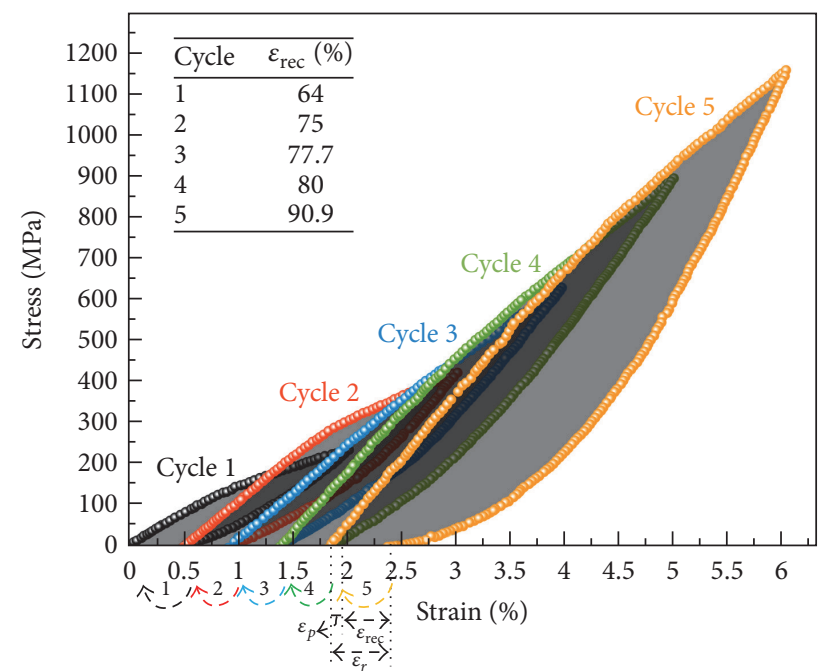

(b)

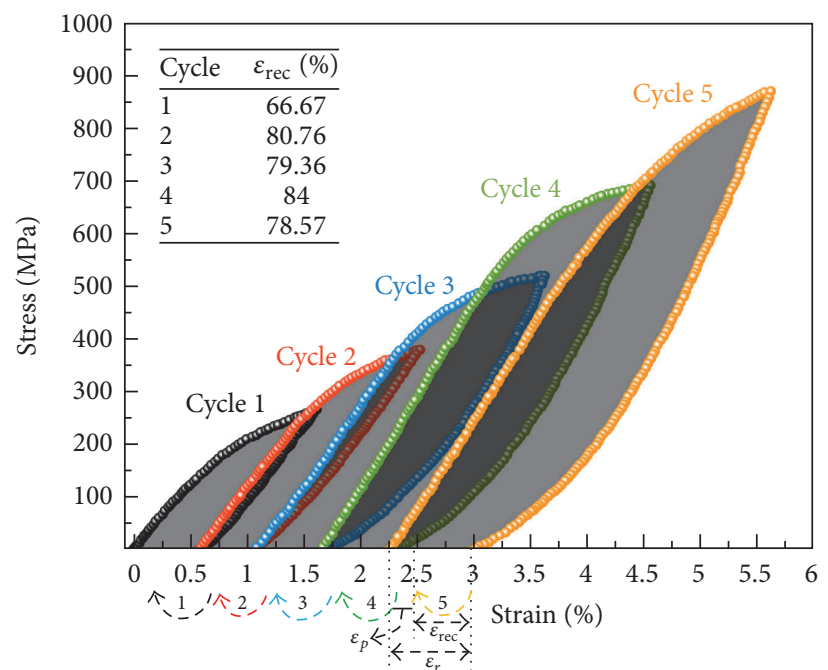

(d)

Figure 5: Stress-strain curves of $\mathrm{Cu}-\mathrm{Al}-\mathrm{Ni}-x \mathrm{Ta} \mathrm{SMAs}$ loaded and unloaded at $200^{\circ} \mathrm{C}$ and then preheated to $300^{\circ} \mathrm{C}$. (a) $\mathrm{Cu}-\mathrm{Al}-\mathrm{Ni}$ and $\mathrm{Cu}-\mathrm{Al}-$ $\mathrm{Ni}-x \mathrm{Ta}$ SMAs with various Ta content: (b) 1.0 , (c) 2.0, and (d) $3.0 \mathrm{wt} . \%$.

TABle 3: Electrochemical parameters of ternary $\mathrm{Cu}-\mathrm{Al}-\mathrm{Ni}$ and quaternary $\mathrm{Cu}-\mathrm{Al}-\mathrm{Ni}-\mathrm{Ta} \mathrm{SMAs}$ in 3 wt.\% $\mathrm{NaCl}$ solution obtained from the polarization test.

\begin{tabular}{|c|c|c|c|c|c|c|}
\hline Alloy & $\begin{array}{c}\text { Corrosion potential, } \\
E_{\text {corr }}(\mathrm{mV} \text { versus } \\
\mathrm{SCE} \text { ) }\end{array}$ & $\begin{array}{l}\text { Current density, } \\
i_{\text {corr }}\left(\mu \mathrm{A} / \mathrm{cm}^{2}\right)\end{array}$ & $\begin{array}{c}\text { Cathodic slope, } \\
\beta_{C}(\mathrm{mV} / \text { decade }) \\
\text { versus SCE }\end{array}$ & $\begin{array}{c}\text { Anodic slope, } \\
\beta_{a} \\
\text { (mV/decade) } \\
\text { versus SCE } \\
\end{array}$ & $\begin{array}{l}\text { Polarization resistance, } \\
\qquad R_{P}\left(\mathrm{k} \Omega \mathrm{cm}^{2}\right)\end{array}$ & $\begin{array}{l}\text { Corrosion rate, } \\
C_{R}(\mathrm{~mm} / \text { year })\end{array}$ \\
\hline $\mathrm{Cu}-\mathrm{Al}-\mathrm{Ni}$ & -261.6 & 117.6 & -211 & 78 & 4.57 & 2.68 \\
\hline $\mathrm{Cu}-\mathrm{Al}-\mathrm{Ni}-1.0 \mathrm{Ta}$ & -220.5 & 78.4 & -184 & 76 & 7.18 & 1.79 \\
\hline $\mathrm{Cu}-\mathrm{Al}-\mathrm{Ni}-2.0 \mathrm{Ta}$ & -185.1 & 32.7 & -148 & 72 & 18.64 & 0.74 \\
\hline $\mathrm{Cu}-\mathrm{Al}-\mathrm{Ni}-3.0 \mathrm{Ta}$ & -159.3 & 12.8 & -220 & 69 & 34.14 & 0.29 \\
\hline
\end{tabular}




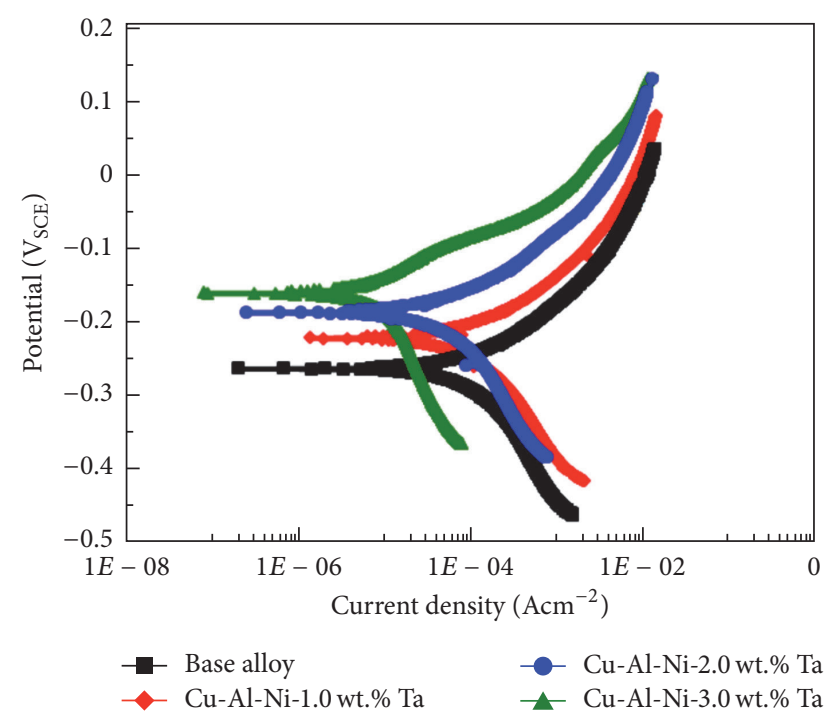

FIgURE 6: Potentiodynamic polarization curves of specimens in 3 wt.\% $\mathrm{NaCl}$ solution. (a) black curve, $\mathrm{Cu}-\mathrm{Al}-\mathrm{Ni}$ and $\mathrm{Cu}-\mathrm{Al}-\mathrm{Ni}-\mathrm{Ta}$ SMAs with various Ta content: (b) red curve, 1.0, (c) blue curve, 2.0, and (d) green curve, $3.0 \mathrm{wt} . \%$.

increased from 4.57 to $7.18 \mathrm{~K} \Omega \mathrm{cm}^{2}$ when a small quantity of Ta (1.0 wt.\%) was added to the base SMA. Further addition of 2.0-3.0 wt.\% Ta to the base SMA leads to a significant increase of $R_{p}$ value in the range of $18.64-34.14 \mathrm{~K} \Omega \mathrm{cm}^{2}$. This indicated that the addition of $3.0 \mathrm{wt} \%$ Ta to base SMA led to the formation of a highly protective passive film even in aggressive chloride-containing solution [54]. In this regard, tantalum-containing alloys showed high corrosion resistance due to spontaneous passivation in aggressive media [56]. Tantalum addition to base SMA leads to a decreasing trend in corrosion rate $\left(C_{R}\right)$, particularly when $3.0 \mathrm{wt}$.\% Ta was added. $C_{R}$ values shown in Table 3 clearly indicate the corrosion rate in the following order: $\mathrm{Cu}-\mathrm{Al}-\mathrm{Ni}, \mathrm{Cu}-\mathrm{Al}-\mathrm{Ni}-1.0 \mathrm{Ta}, \mathrm{Cu}-$ $\mathrm{Al}-\mathrm{Ni}-2.0 \mathrm{Ta}$, and $\mathrm{Cu}-\mathrm{Al}-\mathrm{Ni}-3.0 \mathrm{Ta}$. The lowest corrosion rate of $\mathrm{Cu}-\mathrm{Al}-\mathrm{Ni}-3.0 \mathrm{Ta} \mathrm{SMA}$ is attributed to the presence of a high concentration of Ta ions in the corrosion product film, which has low solubility in aggressive chloride-containing solution [54]. In view of this, it was reported that tantalum is an essential element to improve the corrosion resistance of SMA in aggressive media [56]. Surface morphologies of the $\mathrm{Cu}-\mathrm{Al}-\mathrm{Ni}$ and $\mathrm{Cu}-\mathrm{Al}-\mathrm{Ni}-x \mathrm{Ta}$ SMA after 30 days of immersion in $\mathrm{NaCl}$ solution are shown in Figure 7. Base $\mathrm{Cu}-$ Al-Ni SMA indicated small pits and a significant amount of surface cracking on the surface of the base SMA, which is due to dehydration after removal from the $\mathrm{NaCl}$ solution. The base alloy dissolves actively owing to the formation of the $\mathrm{CuCl}_{2}{ }^{-}$complex anion [53]. From Figure 7(b), the presence of pitting and corrosion products can be observed on the surface of Cu-Al-Ni-1.0 Ta SMA. However, lower amounts of corrosion products were detected after the addition of 2.0 wt.\% Ta to the base SMA (Figure 7(c)). SMA containing $3.0 \mathrm{wt}$ \% $\mathrm{Ta}$ yielded the formation of dense uniform protective films enriched in tantalum ions that cover the entire SMA surface (Figure 7(d)) [57]. A plateau in the anodic polarization curve can clearly be seen, revealing the formation of passive film on the $3.0 \mathrm{wt}$ \% Ta SMA surface [57]. However, Cu-Al-Ni and Cu-Al-Ni-1.0 Ta SMAs were not passivated and dissolved actively, indicating that the 2.03.0 wt. \% Ta addition to the base SMA stabilizes the protective film. This suggests the presence of tantalum in a corrosion product such as tantalum oxyhydroxide film functioning as the effective barrier film. El-Moneim [57] showed that the presence of tantalum in single solid solution phase alloys suppresses the active dissolution process and enhances the protective quality of the passive film formed. EDS analysis (Point 1 ) shows high amounts of $\mathrm{Cu}, \mathrm{Cl}$, and $\mathrm{O}$ accompanied by low content of $\mathrm{Ni}$, indicating the formation of copper compounds in the form of oxide or chloride and aluminum oxide. The presence of Ta (Point 2) further confirmed that tantalum is concentrated in the passive film. In this regard, Badawy et al. [58] reported that, in the corrosion product in ternary aluminum-containing copper alloys composed of two layers, the under layer is $\mathrm{Cu}_{2} \mathrm{O} \cdot \mathrm{Al}_{2} \mathrm{O}_{3} \cdot x \mathrm{H}_{2} \mathrm{O}$, the overlayer, is a mixture of $\mathrm{Al}_{2} \mathrm{O}_{3}$ and $\mathrm{Cu}_{2} \mathrm{O}$. However, Montecinos and Simison [59] suggested that the corrosion product of the $\mathrm{Cu}-\mathrm{Al}-\mathrm{Be} \mathrm{SMA}$ in chloride media is composed of $\mathrm{Al}_{2} \mathrm{O}_{3} \cdot \mathrm{H}_{2} \mathrm{O}, \mathrm{Cu}_{2} \mathrm{O}, \mathrm{CuO},\left(\mathrm{CuCO}_{3} \cdot \mathrm{Cu}(\mathrm{OH})_{2}\right)$, and $\mathrm{CuCl}_{2}$. In view of this, the formation of protective tantalum-enriched film in addition to $\mathrm{Al}$-dihydroxychloride, $\mathrm{Cu}$-oxides, and $\mathrm{Cu}$ chlorides is responsible for the high corrosion resistance of Cu-Al-Ni-Ta SMA.

\section{Conclusions}

The Cu-Al-Ni alloy as a potential type of shape memory alloy was successfully produced by powder metallurgy, mechanical alloying, and microwave sintering. The addition effects of different amounts of $\mathrm{Ta}$ on the microstructure, transformation temperature, damping capacity, shape memory effect, and corrosion behaviour were systematically investigated and the main conclusions are as follows:

(1) After the microwave sintering at $900^{\circ} \mathrm{C}$, the Ta particles were uniformly distributed in the matrix of $\mathrm{Cu}$ $\mathrm{Al}-\mathrm{Ni}$, and different types of precipitates were formed in the binding domain between the $\mathrm{Ta}$ and $\mathrm{Al} / \mathrm{Ni}$ phase.

(2) The porosity density and grain size were reduced after the addition of $\mathrm{Ta}$, in which the smallest grain size and lowest porosity were observed in prealloyed $\mathrm{Cu}-\mathrm{Al}-\mathrm{Ni}$ after being modified with $2.0 \mathrm{wt} . \%$ Ta.

(3) The highest transformation temperatures and strain recovery by shape memory effect were indicated in prealloyed $\mathrm{Cu}-\mathrm{Al}-\mathrm{Ni}-2.0$ wt.\% Ta, while the highest internal friction was present in the prealloyed $\mathrm{Cu}-\mathrm{Al}$ Ni-3.0 wt.\% Ta. These variations are mainly attributed to the density of porosity, grain refinement, and presence of precipitates, whereas these parameters significantly control the movement of martensite interfaces and dislocations, thus controlling the mechanical properties.

(4) The electrochemical corrosion performance of the $\mathrm{Cu}-\mathrm{Al}-\mathrm{Ni}-\mathrm{Ta} \mathrm{SMA}$ was enhanced via increasing the 

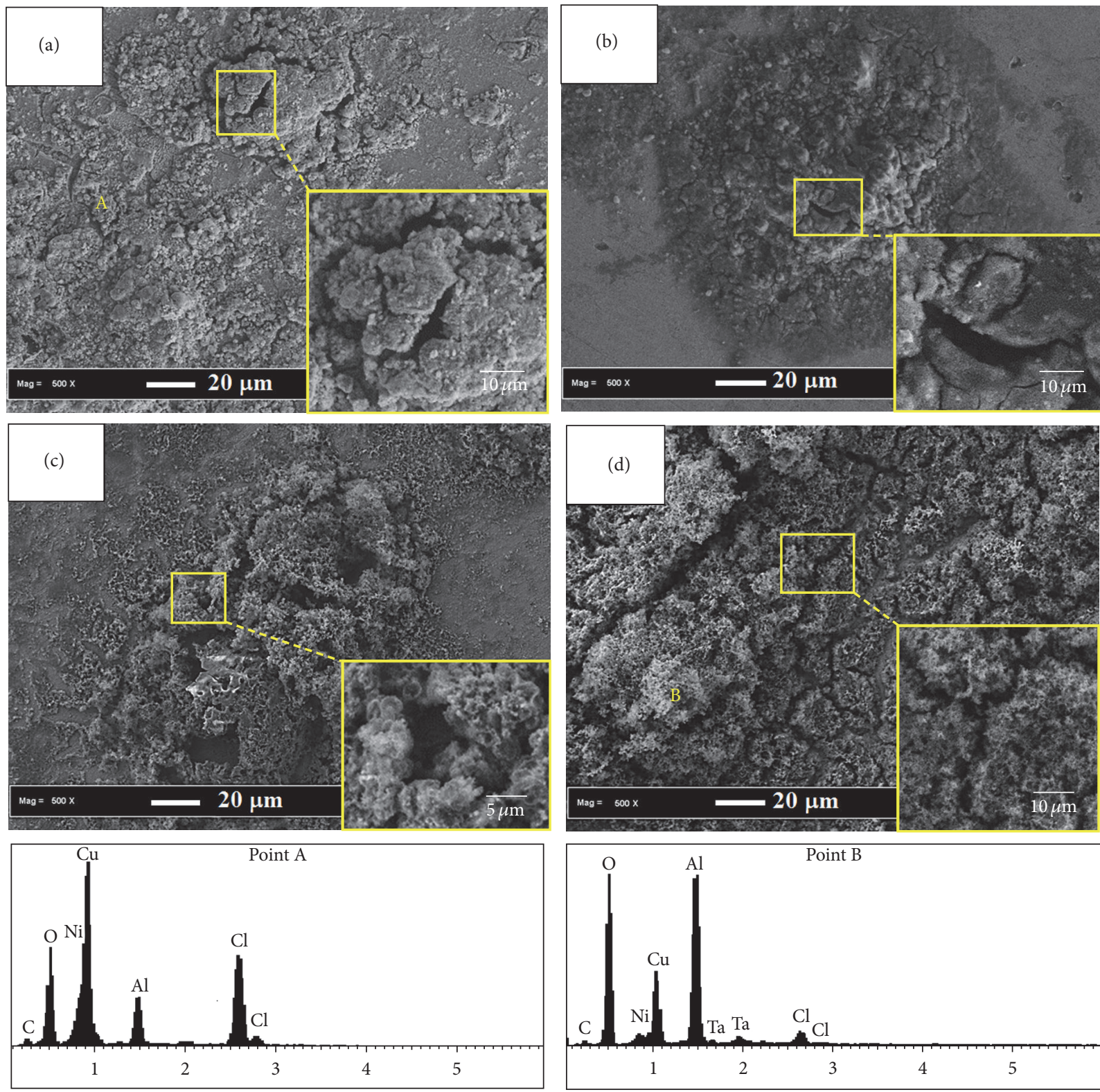

Figure 7: SEM micrographs of (a) Cu-Al-Ni and Cu-Al-Ni- $x$ Ta SMAs with various Ta content: (b) 1.0, (c) 2.0, and (d) 3.0 wt.\%; and corresponding EDS analyses of points $\mathrm{A}$ and $\mathrm{B}$ after immersion into $3 \mathrm{wt} . \% \mathrm{NaCl}$ for 30 days.

Ta concentration. The result also indicated that a more stable passive oxide film containing tantalum oxyhydroxide formed on the surface of $\mathrm{Cu}-\mathrm{Al}-\mathrm{Ni}-3.0$ Ta SMA, which resulted in better corrosion resistance compared with the other SMAs.

\section{Competing Interests}

The authors declare that they have no competing interests.

\section{Acknowledgments}

The authors would like to thank the Ministry of Higher Education of Malaysia and Universiti Teknologi Malaysia for providing the financial support under the University Research Grant no. Q.J130000.3024.00 M57 and research facilities.

\section{References}

[1] Z. C. Lin, W. Yu, R. H. Zee, and B. A. Chin, "CuAlPd alloys for sensor and actuator applications," Intermetallics, vol. 8, no. 5-6, pp. 605-611, 2000.

[2] J. Font, E. Cesari, J. Muntasell, and J. Pons, "Thermomechanical cycling in Cu-Al-Ni-based melt-spun shape-memory ribbons," Materials Science and Engineering A, vol. 354, no. 1-2, pp. 207211, 2003.

[3] T. Tadaki, K. Otsuka, and C. M. Wayman, "Shape memory materials," Cu-based shape memory alloys, pp. 97-116, 1998. 
[4] S. Miyazaki, K. Otsuka, H. Sakamoto, and K. Shimizu, "The fracture of $\mathrm{Cu}-\mathrm{Al}-\mathrm{Ni}$ shape memory alloy," Transactions of the Japan Institute of Metals, vol. 22, no. 4, pp. 244-252, 1981.

[5] S. W. Husain and P. C. Clapp, "The intergranular embrittlement of Cu-AI-Ni $\beta$-phase alloys," Journal of Materials Science, vol. 22, no. 7, pp. 2351-2356, 1987.

[6] S. N. Saud, T. A. Abu Bakar, E. Hamzah, M. K. Ibrahim, and A. Bahador, "Effect of quarterly element addition of cobalt on phase transformation characteristics of $\mathrm{Cu}-\mathrm{Al}-\mathrm{Ni}$ shape memory alloys," Metallurgical and Materials Transactions A, vol. 46, no. 8, pp. 3528-3542, 2015.

[7] S. N. Saud, E. Hamzah, T. Abubakar, M. K. Ibrahim, and A. Bahador, "Effect of a fourth alloying element on the microstructure and mechanical properties of $\mathrm{Cu}-\mathrm{Al}-\mathrm{Ni}$ shape memory alloys," Journal of Materials Research, vol. 30, no. 14, pp. 22582269, 2015.

[8] S. N. Saud, E. Hamzah, T. Abubakar, and H. R. Bakhsheshi-Rad, "Correlation of microstructural and corrosion characteristics of quaternary shape memory alloys $\mathrm{Cu}-\mathrm{Al}-\mathrm{Ni}-\mathrm{X}(\mathrm{X}=\mathrm{Mn}$ or $\mathrm{Ti})$, Transactions of Nonferrous Metals Society of China, vol. 25, no. 4, Article ID 63711, pp. 1158-1170, 2015.

[9] M. A. Morris, "Microstructural influence on ductility and shape memory effect of some modified Cu-Ni-Al alloys," Scripta Metallurgica et Materiala, vol. 25, no. 6, pp. 1409-1414, 1991.

[10] Y. Gao, M. Zhu, and J. K. L. Lai, "Microstructure characterization and effect of thermal cycling and ageing on vanadiumdoped $\mathrm{Cu}-\mathrm{Al}-\mathrm{Ni}-\mathrm{Mn}$ high-temperature shape memory alloy," Journal of Materials Science, vol. 33, no. 14, pp. 3579-3584, 1998.

[11] V. Recarte, R. B. Pérez-Sáez, E. H. Bocanegra, M. L. Nó, and J. San Juan, "Dependence of the martensitic transformation characteristics on concentration in $\mathrm{Cu}-\mathrm{Al}-\mathrm{Ni}$ shape memory alloys," Materials Science and Engineering: A, vol. 273-275, pp. 380-384, 1999.

[12] V. Recarte, R. B. Pérez-Sáez, E. H. Bocanegra, M. L. Nó, and J. San Juan, "Influence of $\mathrm{Al}$ and $\mathrm{Ni}$ concentration on the martensitic transformation in $\mathrm{Cu}-\mathrm{Al}-\mathrm{Ni}$ shape-memory alloys," Metallurgical and Materials Transactions A, vol. 33, no. 8, pp. 2581-2591, 2002.

[13] S. K. Vajpai, R. K. Dube, and S. Sangal, "Microstructure and properties of $\mathrm{Cu}-\mathrm{Al}-\mathrm{Ni}$ shape memory alloy strips prepared via hot densification rolling of argon atomized powder preforms," Materials Science and Engineering A, vol. 529, no. 1, pp. 378-387, 2011.

[14] G. Lojen, I. Anžel, A. Kneissl et al., "Microstructure of rapidly solidified $\mathrm{Cu}-\mathrm{Al}-\mathrm{Ni}$ shape memory alloy ribbons," Journal of Materials Processing Technology, vol. 162-163, pp. 220-229, 2005.

[15] S. K. Vajpai, R. K. Dube, and S. Sangal, "Processing and characterization of $\mathrm{Cu}-\mathrm{Al}-\mathrm{Ni}$ shape memory alloy strips prepared from prealloyed powder by hot densification rolling of powder preforms," Metallurgical and Materials Transactions A: Physical Metallurgy and Materials Science, vol. 42, no. 10, pp. 3178-3189, 2011.

[16] C. Suryanarayana, Non-Equilibrium Processing of Materials, vol. 2, Elsevier, 1999.

[17] M. F. Giordana, M. R. Esquivel, and E. Zelaya, "A detailed study of phase evolution in $\mathrm{Cu}-16$ at. $\% \mathrm{Al}$ and $\mathrm{Cu}-30$ at. \%Al alloys under different types of mechanical alloying processes," Advanced Powder Technology, vol. 26, no. 2, pp. 470-477, 2015.

[18] B. Y. Li, L. J. Rong, Y. Y. Li, and V. E. Gjunter, "Synthesis of porous Ni-Ti shape-memory alloys by self-propagating hightemperature synthesis: reaction mechanism and anisotropy in pore structure," Acta Materialia, vol. 48, no. 15, pp. 3895-3904, 2000.

[19] Y. Zhao, M. Taya, Y. Kang, and A. Kawasaki, "Compression behavior of porous NiTi shape memory alloy," Acta Materialia, vol. 53, no. 2, pp. 337-343, 2005.

[20] B. Yuan, X. P. Zhang, C. Y. Chung, M. Q. Zeng, and M. $\mathrm{Zhu}$, "A comparative study of the porous TiNi shape-memory alloys fabricated by three different processes," Metallurgical and Materials Transactions A, vol. 37, no. 3, pp. 755-761, 2006.

[21] F. Kongoli, "Sohn International Symposium on 'advanced processing of metals and materials," Transactions of the Institutions of Mining and Metallurgy, vol. 117, no. 2, pp. 65-66, 2008.

[22] M. Oghbaei and O. Mirzaee, "Microwave versus conventional sintering: a review of fundamentals, advantages and applications," Journal of Alloys and Compounds, vol. 494, no. 1-2, pp. 175-189, 2010.

[23] H. Y. Kim, S. Hashimoto, J. I. Kim, T. Inamura, H. Hosoda, and S. Miyazaki, "Effect of Ta addition on shape memory behavior of Ti-22Nb alloy," Materials Science and Engineering A, vol. 417, no. 1-2, pp. 120-128, 2006.

[24] J. Liu, H. X. Zheng, M. X. Xia, and J. G. Li, “The microstructure and martensitic transformation of $\mathrm{Co}-\mathrm{Ni}-\mathrm{Ga}-\mathrm{Ta}$ ferromagnetic shape memory alloys," Scripta Materialia, vol. 52, no. 10, pp. 955-958, 2005.

[25] W. Y. Peng, N. W. Yang, G. L. Qu, W. W. Wang, H. P. Shi, and W. J. Wang, "Effect of ta addition on properties and microstructures of Fe-28Ni-11.5Al shape memory alloys," Materials Science Forum, vol. 787, pp. 288-294, 2014.

[26] X. Rao, C. L. Chu, and Y. Y. Zheng, "Phase composition, microstructure, and mechanical properties of porous $\mathrm{Ti}-\mathrm{Nb}-$ $\mathrm{Zr}$ alloys prepared by a two-step foaming powder metallurgy method," Journal of the Mechanical Behavior of Biomedical Materials, vol. 34, pp. 27-36, 2014.

[27] Y.-W. Kim, K.-C. Choi, Y.-S. Chung, E. Choi, and T.-H. Nam, "Microstructure and martensitic transformation characteristics of gas-atomized Ti-Ni-Cu powders," Journal of Alloys and Compounds, vol. 577, supplement 1, pp. S227-S231, 2013.

[28] A. S. Jabur, J. T. Al-Haidary, and E. S. Al-Hasani, "Characterization of Ni-Ti shape memory alloys prepared by powder metallurgy," Journal of Alloys and Compounds, vol. 578, pp. 136142, 2013.

[29] G. R. Argade, K. Kandasamy, S. K. Panigrahi, and R. S. Mishra, "Corrosion behavior of a friction stir processed rare-earth added magnesium alloy," Corrosion Science, vol. 58, pp. 321-326, 2012.

[30] H. R. Bakhsheshi-Rad, M. R. Abdul-Kadir, M. H. Idris, and S. Farahany, "Relationship between the corrosion behavior and the thermal characteristics and microstructure of $\mathrm{Mg}-0.5 \mathrm{Ca}-$ $x$ Zn alloys," Corrosion Science, vol. 64, pp. 184-197, 2012.

[31] Z. Shi, M. Liu, and A. Atrens, "Measurement of the corrosion rate of magnesium alloys using Tafel extrapolation," Corrosion Science, vol. 52, no. 2, pp. 579-588, 2010.

[32] K. A. Darling, A. J. Roberts, Y. Mishin, S. N. Mathaudhu, and L. J. Kecskes, "Grain size stabilization of nanocrystalline copper at high temperatures by alloying with tantalum," Journal of Alloys and Compounds, vol. 573, pp. 142-150, 2013.

[33] P. C. Millett, R. P. Selvam, and A. Saxena, "Stabilizing nanocrystalline materials with dopants," Acta Materialia, vol. 55, no. 7, pp. 2329-2336, 2007.

[34] S. N. Saud, E. Hamzah, T. Abubakar, H. R. Bakhsheshi-Rad, M. Zamri, and M. Tanemura, "Effects of Mn additions on the 
structure, mechanical properties, and corrosion behavior of $\mathrm{Cu}$ Al-Ni shape memory alloys," Journal of Materials Engineering and Performance, vol. 23, no. 10, pp. 3620-3629, 2014.

[35] S. N. Saud, E. Hamzah, T. Abubakar, M. Zamri, and M. Tanemura, "Influence of Ti additions on the martensitic phase transformation and mechanical properties of $\mathrm{Cu}-\mathrm{Al}-\mathrm{Ni}$ shape memory alloys," Journal of Thermal Analysis and Calorimetry, vol. 118, no. 1, pp. 111-122, 2014.

[36] V. Sampath, "Studies on the effect of grain refinement and thermal processing on shape memory characteristics of $\mathrm{Cu}-\mathrm{Al}$ Ni alloys," Smart Materials and Structures, vol. 14, no. 5, pp. S253-S260, 2005.

[37] Y. Aydogdu, A. Aydogdu, and O. Adiguzel, "Selfaccommodating martensite plate variants in shape memory CuAlNi alloys," Journal of Materials Processing Technology, vol. 123, no. 3, pp. 498-500, 2002.

[38] C. Booth-Morrison, R. D. Noebe, and D. N. Seidman, "Effects of a tantalum addition on the morphological and compositional evolution of a model Ni-Al-Cr superalloy," in Proceedings of the 11th International Symposium on Superalloys (SuperAlloys '08), pp. 73-79, Champion, Pa, USA, September 2008.

[39] F. C. Lovey and E. Cesari, "On the microstructural characteristics of non-equilibrium $\gamma$ precipitates in $\mathrm{Cu}-\mathrm{Zn}-\mathrm{Al}$ alloys," Materials Science and Engineering A, vol. 129, no. 1, pp. 127-133, 1990.

[40] M. Zarinejad, Y. Liu, and Y. Tong, "Transformation temperature changes due to second phase precipitation in NiTi-based shape memory alloys," Intermetallics, vol. 17, no. 11, pp. 914-919, 2009.

[41] B. Yuan, X. P. Zhang, C. Y. Chung, and M. Zhu, "The effect of porosity on phase transformation behavior of porous Ti50.8 at.\% Ni shape memory alloys prepared by capsule-free hot isostatic pressing," Materials Science and Engineering A, vol. 438-440, pp. 585-588, 2006.

[42] A. Nespoli, E. Villa, and F. Passaretti, "Effect of Yttrium on microstructure, thermal properties and damping capacity of $\mathrm{Ni}_{41} \mathrm{Ti}_{50} \mathrm{Cu}_{9}$ alloy," Journal of Alloys and Compounds, vol. 653, pp. 234-242, 2015.

[43] K.-N. Lin and S.-K. Wu, "Multi-stage transformation in annealed $\mathrm{Ni}$-rich $\mathrm{Ti}_{49} \mathrm{Ni}_{41} \mathrm{Cu}_{10}$ shape memory alloy," Intermetallics, vol. 18, no. 1, pp. 87-91, 2010.

[44] Y.-P. Zhang and X.-P. Zhang, "Internal friction behaviors of porous NiTi alloys with variable porosities," Chinese Journal of Nonferrous Metals, vol. 19, no. 10, pp. 1872-1879, 2009.

[45] H.-J. Jiang, C.-B. Ke, S.-S. Cao, X. Ma, and X.-P. Zhang, "Phase transformation and damping behavior of lightweight porous TiNiCu alloys fabricated by powder metallurgy process," Transactions of Nonferrous Metals Society of China (English Edition), vol. 23, no. 7, pp. 2029-2036, 2013.

[46] Q. Wang, C. Cui, N. Yan, and F. Han, "Internal friction peaks in a porous CuAlMn shape memory alloy," Advanced Materials Research, vol. 479-481, pp. 1303-1306, 2012.

[47] Q. Wang, F. Han, J. Wu, and G. Hao, "Damping behavior of porous CuAlMn shape memory alloy," Materials Letters, vol. 61, no. 11-12, pp. 2598-2600, 2007.

[48] A. S. Nowick, Anelastic Relaxation in Crystalline Solids, vol. 1, Elsevier, Amsterdam, Netherlands, 2012.

[49] U. Sari and I. Aksoy, "Micro-structural analysis of selfaccommodating martensites in $\mathrm{Cu}-11.92 \mathrm{wt} \% \mathrm{Al}-3.78 \mathrm{wt} \% \mathrm{Ni}$ shape memory alloy," Journal of Materials Processing Technology, vol. 195, no. 1-3, pp. 72-76, 2008.
[50] J. Dutkiewicz, "Superelasticity and shape memory effect in copper base alloys," Acta Physica Polonica A, vol. 96, no. 2, pp. 197-212, 1999.

[51] X. L. Meng, Y. F. Zheng, Z. Wang, and L. C. Zhao, "Shape memory properties of the $\mathrm{Ti}_{36} \mathrm{Ni}_{49} \mathrm{Hf}_{15}$ high temperature shape memory alloy," Materials Letters, vol. 45, no. 2, pp. 128-132, 2000.

[52] Q. M. Nafari and S. M. Abbasi, "Influence of composition and thermomechanical training process on the transformation behavior and shape memory properties of NiTi based alloys," Transactions of the Indian Institute of Metals, vol. 66, no. 3, pp. 239-245, 2013.

[53] C. Qin, W. Zhang, K. Asami, N. Ohtsu, and A. Inoue, "Glass formation, corrosion behavior and mechanical properties of bulk glassy Cu-Hf-Ti-Nb alloys," Acta Materialia, vol. 53, no. 14, pp. 3903-3911, 2005.

[54] H.-J. Lee, E. Akiyama, H. Habazaki, A. Kawashima, K. Asami, and K. Hashimoto, "The roles of tantalum and phosphorus in the corrosion behavior of Ni-Ta-P alloys in $12 \mathrm{M} \mathrm{HCl,"} \mathrm{Corrosion}$ Science, vol. 39, no. 2, pp. 321-332, 1997.

[55] S. Montecinos and S. Simison, "Corrosion behavior of $\mathrm{Cu}-$ Al-Be shape memory alloys with different compositions and microstructures," Corrosion Science, vol. 74, pp. 387-395, 2013.

[56] J. Bhattarai, E. Akiyama, H. Habazaki, A. Kawashima, K. Asami, and K. Hashimoto, "The passivation behavior of sputterdeposited W-Ta alloys in $12 \mathrm{M} \mathrm{HCl,"} \mathrm{Corrosion} \mathrm{Science,} \mathrm{vol.} \mathrm{40,}$ no. 4-5, pp. 757-779, 1998.

[57] A. A. El-Moneim, E. Akiyama, H. Habazaki, A. Kawashima, K. Asami, and K. Hashimoto, "The corrosion behaviour of sputterdeposited amorphous $\mathrm{Mn}$-Ta alloys in $0.5 \mathrm{M} \mathrm{NaCl}$ solution," Corrosion Science, vol. 39, no. 10-11, pp. 1965-1979, 1997.

[58] W. A. Badawy, M. M. El-Rabiei, and H. Nady, "Synergistic effects of alloying elements in Cu-ternary alloys in chloride solutions," Electrochimica Acta, vol. 120, pp. 39-45, 2014.

[59] S. Montecinos and S. N. Simison, "Influence of the microstructure on the corrosion behaviour of a shape memory $\mathrm{Cu}-\mathrm{Al}-\mathrm{Be}$ alloy in a marine environment," Applied Surface Science, vol. 257, no. 7, pp. 2737-2744, 2011. 

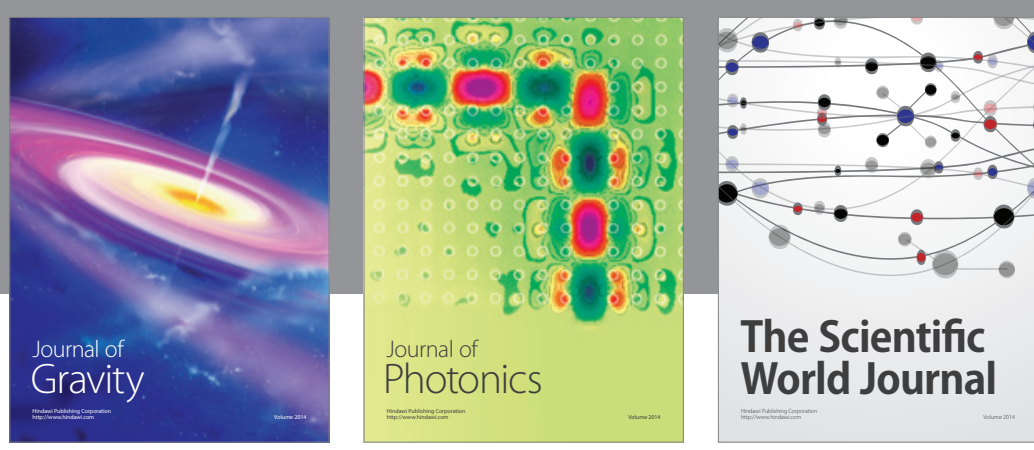

The Scientific World Journal
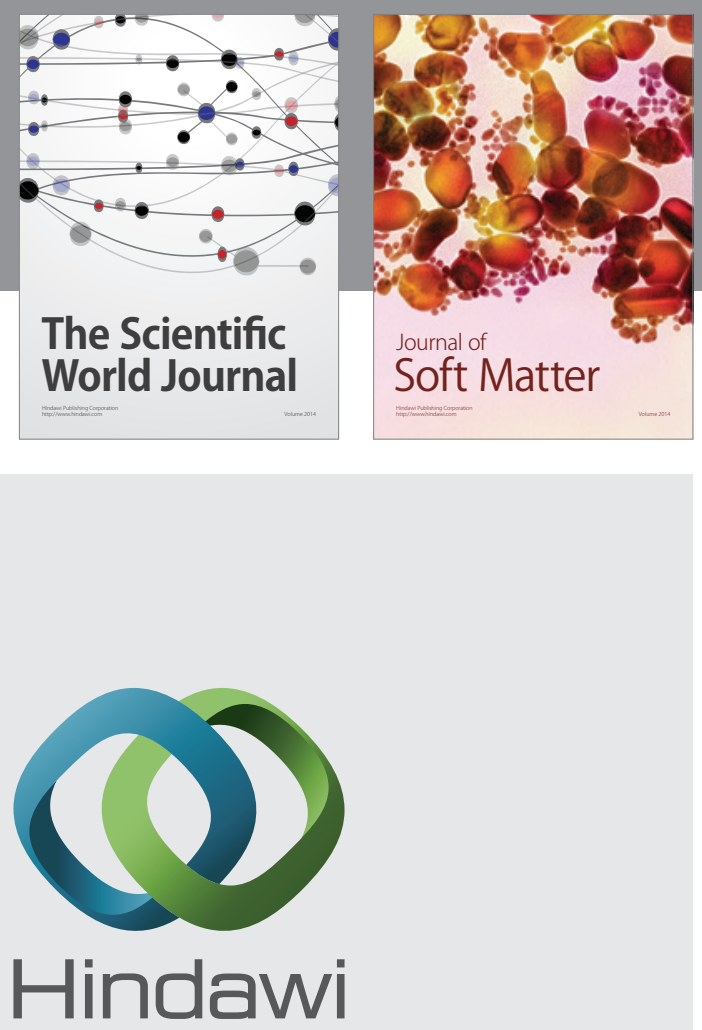

Submit your manuscripts at

https://www.hindawi.com
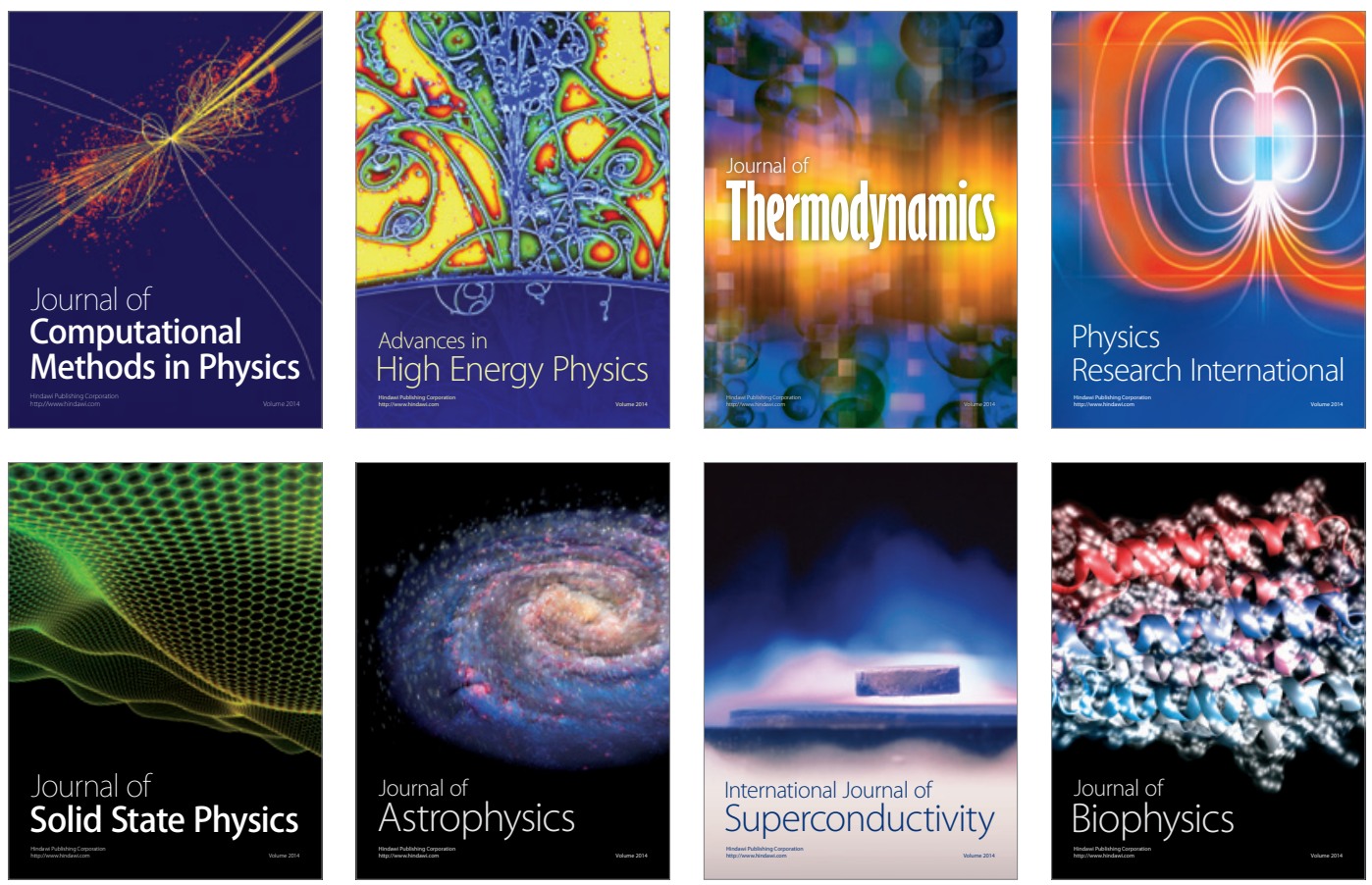
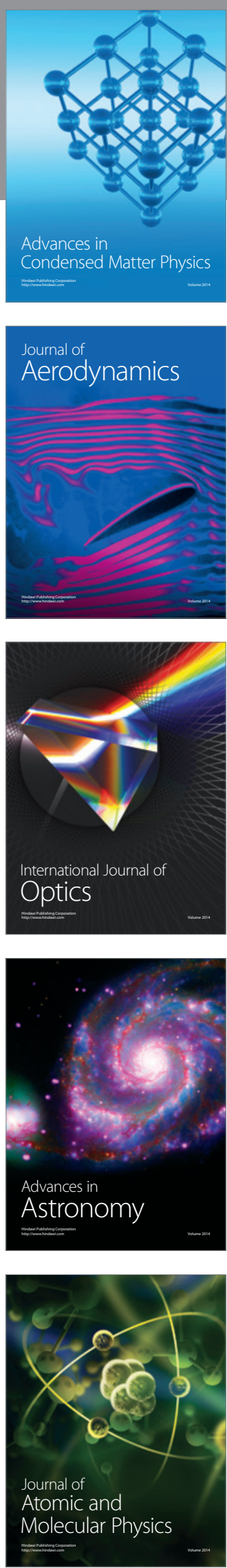